\title{
The Urban Governance Crisis: When Housing Cooperatives Make the City-The Case of Khenifra in Morocco
}

\author{
Mohamed Marou'1, Said Azelmad² \\ ${ }^{1}$ A Ph.D. Condidate in the Laboratory of Environment, Development and Space Management, Faculty of Lettres and Human \\ Sciences, Kenitra, Marocco \\ ${ }^{2}$ A Ph.D. Candidate in the Laboratory of Discourse, Creativity and Society Perceptions and Implications, Faculty of Arts and \\ Humanities, Sais, Fes, Morocco \\ Email: marou7575@gmail.com, said.azelmad@usmba.ac.ma
}

How to cite this paper: Marou, M., \& Azelmad, S. (2020). The Urban Governance Crisis: When Housing Cooperatives Make the City-The Case of Khenifra in Morocco. Current Urban Studies, 8, 241-252. https://doi.org/10.4236/cus.2020.82013

Received: April 3, 2020

Accepted: May 22, 2020

Published: May 25, 2020

Copyright $\odot 2020$ by author(s) and Scientific Research Publishing Inc. This work is licensed under the Creative Commons Attribution International License (CC BY 4.0).

http://creativecommons.org/licenses/by/4.0/ (c) (i) Open Access

\begin{abstract}
The abuse in public land assets with no particular effort to renew it, and the implementation of Law $25 / 90^{1}$ have led to a dizzying rise in land values that continue to affect urban land on a sustainable level. The following situation is combined with the scarcity or even absence of varied social housing ${ }^{2}$, which affected directly the conditions of access to land assets in the city of Khenifra and Morocco in general. Today, housing costs are rising faster than household income levels. This situation has resulted in the development of a group of housing cooperatives that play a dual role of collecting and encouraging savings, carrying out subdivisions and infrastructure construction meanwhile. The birth of this self-help housing type in Khenifra dates back to 1993, when a first housing cooperative called $A l A r z$, initiated by a group of teachers, laid the foundations for a practice that would later become a sustainable phenomenon that impeded the city's urban planning and governance.
\end{abstract}

\section{Keywords}

Housing Governance, Housing Cooperatives, Sustainable Urbanism, Urban Planning, Morocco

\section{Introduction}

Housing cooperatives have become one of the major components of the so${ }^{1}$ Dahir No. 1-92-7 of 15 Hija 1412 (17 June 1992) promulgating Act No. 25-90 on allotments, housing groups, and subdivisions in Morocco has reduced the flexibility of regulatory developers.

${ }^{2}$ Low-cost housing project, which still falls short of needs. 
cio-spatial organization of the mid-sized Moroccan cities (Marou, 2015). DEP (2005) defines the cooperative as a group of physical people who agree to group together to create a company provide, for their exclusive satisfaction, a product or service that they need. In terms of housing, the cooperative aims to build housing, as a principal residence, on behalf of its members. Therefore, a housing cooperative is a collective movement or a collective action to achieve a common goal in the best conditions of performance and efficiency. It is interested in housing works with the cheapest prices to improve the well-being of its shareholders. However, if this movement has experienced a real expansion over the last decade, summoning up more shareholders to look for housing with the lowest costs ${ }^{3}$ to the various segments of the population (DEP, 2005). Nevertheless, it prevents, to a large extent, the proper spatial organization aimed at promoting the well-being of all the population. All in all, the interest in writing this article emanates from the fact that the increasing movement of housing cooperatives begins to occupy a real developing process of urban spaces in the country, taking an emergency character in urban governance and planning. Day in day out, the new phenomenon impedes the process of urban planning, unveiling the veil upon the state's inability to carry out clear and pertinent policies on urban land production and protection.

\section{What is a Housing Cooperative?}

The housing cooperative is a part of the association movement. A movement that brings together all associations and any other group founded by the law to improve their living environment, in terms of housing, development, restructuring or equipment in the various cities of the kingdom (DEP, 2005). A Housing cooperative is an alternate form of home ownership, in which the land is sold, equipped and sold in lots to the shareholders of the cooperative, who have contributed by their shares along the process. It is a philosophy which is encouraged by the Ministry of Urban Planning and Housing in order to increase descent housing for all the social classes and fight against all forms of unhealthy lodging, encouraging social integration and family tranquility among the housing cooperatives (DEP, 2005). Legally, the housing cooperation or association is governed by the rule of law or Dahir ${ }^{4}$ No. 1-58-376 of November 27, $1958^{5}$, as it was modified or completed in 1973 and again in 2002. This law makes no distinction between housing cooperation and association. In the Moroccan context, a housing cooperative is referred to as a group of individuals who organize themselves legally in an association to acquire land collectively to be subdivided,

\footnotetext{
${ }^{3}$ These groups charge prices $20 \%$ to $30 \%$ lower than professionals based mainly on the tax exemption that manifests itself through a set of benefits such as registration fees, housing cooperatives are taxed at a reduced rate of $2.5 \%$ on the value of the land acquired instead of the normal rate of $5 \%$. Besides, the deeds of the constitution and dissolution of cooperatives, as well as their bank bonding or mortgage deeds, are exempt from registration and stamp fees. Source: http://www.yabiladi.ma/. ${ }^{4} \mathrm{~A}$ Dahir is an Arabic word which means the Moroccan King's decree.

${ }^{5}$ Refer to the Official Gazette of November 27 page 1909.
} 
after infrastructure equipment, into individual lots with a lower cost in comparison with the rates of the real estate. Later, everyone can proceed to the construction of his lot or sell it for befit. In Morocco, the housing cooperative is labeled as the Amicale in French or Widadiya in Arabic, which is different from Housing cooperative in Europe or USA, referred to as Home Clubs.

\section{Urban Planning and Local Development: Two Interdependent Concepts}

The word development is a large concept that summarizes the economic and social prosperity of individuals in their relation to employment and housing. The concept of development has a steady connection with the environmental aspect and the well-being of individuals, which should be surrounded by green spaces surrounding their housing cooperatives as well. In this regard, most of the housing surroundings are deprived of the aesthetic dimension, hygiene, and integrated child and adult basic services (Mandelker, 1981). In this way, housing cooperatives must respect the minimum housing ordinance, dictated by the rule of law standards. These requirements are now part of a broader and more ambitious approach to the promotion of the whole spatial and social ensemble (Perrin, 1989). In this sense, the state should intervene carefully to save urban planning, enhancing the aesthetic attractiveness of the city. Normally, this sense for aesthetics is absented, because of the increasing greed of offices who prefer to increase the numbers of lots more than the quality of life inside these housing cooperatives. It is true that the social juxtapositions in Morocco do, now, exercise a general pressure on the ministry in charge to offer an affordable housing supply, especially for law-income families. However, it is very import for the ministry to reconsider also the opportunities of local development and rationalized spatial organization of urban spaces and their consumption in connection to their governance and planning for effective territorial investments that respect local urbanity of the cities and their social functions, ordained also to enhance the quality of life and the beauty of cities (Sazama, 2000). In this way, the rigorous practice of urban spatial planning, which is purely a responsibility of urban planners, technicians, and specialists becomes an activity of other planners who are sometimes mere real estate speculators. The phenomenon becomes, then, a hazardous popular spatial planning, absented from necessary equipment and civil services and mandatory for local development and sustainable urbanism.

\section{The Housing Cooperatives in Khenifra: The Urban Context of Emergence}

The rigorous practice of urban planning is a big responsibility of planners, technicians and specialists. The emerging phenomenon of the housing cooperatives inclines rather towards what can be called popular planning of space (Marou, 2015). ${ }^{6}$ Apartments or buildings are distributed by size and location, and they can be sold profitably by the shareholders (Carswell, 2012). 
A planning that manifests itself through the exclusive production of housing and where the equipment and services necessary for local development are marginalized though. In this way, the birth of these new phenomenon can not be ruled out of the crisis in spatial dimensions, from which it draws its raison d'être. Apparently, the excessive consumption of public land heritage, without any particular effort to renew it, and the implementation of Law 25/90 which had reduced the former maneuverability to exploit the public soil easily, without any further supply, equipment or organization, have augmented the value in the urban surrounding soil in Morocco and Khenifra ${ }^{7}$ in particular. Historically and after the end of the colonial era in Khenifra, the land recovery and recoupment from the colonizer has contributed in a sense to the complexity and inexactitude of the urban soil, dominated by the heirs of Mouha Ou Hammou Zayani, who had built up an outstanding land heritage at the level of the entire area (Jari, 1999). The situation of the following inherited soil has become more complex throughout time, following the illegal acquisition of land, conflicts and disputes between buyers and sellers, which weighed heavily on the urban planning process. Since the Moroccan independence, most of the cities have been gradually engaged in a real estate speculation throughout time, the process which baffled and confused the urban planners of the kingdom. These dysfunctions in urban vision have yielded real handicapped urbanisation pay-offs for the city designers. It has given emergence to other land speculators outside the regulatory framework of sustainable urbanization (El Malti, 2006, 2013). Indeed, what added yeast to the brew is the scarcity, or even the absence of VIT ${ }^{8}$ social housing in Khenifra. The following factor has also a direct impact on the living and rental conditions of poor families, especially in a context marked by a weak economic base and where the supply of employment remains weak; while housing costs keep increasing faster than household incomes day in day out. As a result, this urban crisis has mainly affected the middle class, which could not dwell in neighborhoods of poor living conditions, looking for alternative means to create a medium standing dwelling. This weakness of the financial capacity of the middle class has resulted in the development of housing cooperatives that play the dual role of collecting and encouraging savings, carrying out subdivision meanwhile (Lehzam, 1994). So far, all these factors are enough to melt down the solutions of the state and give birth for a freehanded social housing, which is the friendly housing of citizen cooperatives. The first cooperative-Al Arz-was established in 1993 by a group of teachers, sowed the seeds for a new phenomenon that hind-

\footnotetext{
${ }^{7}$ Is an old Amazigh (Zayan) city in Morocco, which is always remembered by its historic leader Mouha Ou Hammou Zayani, the Atlas lion in the guerrilla battles against the French colonization in the mountains of Zayan (Marou, Azelmad, Hanzaz, \& Bouzidi, 2019).

${ }^{8}$ Which means Valeur Immobilière Totale in French, or with low total real estate value (LRV) in English. It is a product of social housing which covers the area of 50 to $60 \mathrm{~m}^{2}$, this type of social housing is prohibited to exceed the price of 140,000 Dirhams all over the country. It is launched by the Ministry of Housing, Urbanism and Urban Policy, in 2008, to best meet the housing demands of middle class citizens, with the endeavors of the state to improve the living conditions of disadvantaged population.
} 
ers now the urban planning in the city.

\section{Housing Cooperatives in Khenifra: A Booming Movement}

This type of housing has experienced remarkable growth, since the birth and success of the first housing cooperative in Khenifra in 1993. Figure 1 indicates accordingly the evolution in the number of housing cooperatives created between 1993 and 2012.

Figure 1 indicates how the creation of the first housing cooperative between 1993 and 2012 follows directly the agglomeration of the cooperatives after the release of a very important urban document, which is the Management Plan. Therefore, the evolution of this type of operation follows a certain logic; it is during the periods when the city's Management Plan is under deliberation that the most important changes take place. In other words, the creation of housing cooperatives in the city of Khenifra always precedes the launching of each Management Plan. They reach their peak at the time of its release and register a decline in the final phases of its elaboration. Moreover, this associative movement has accentuated the phenomenon of land speculation and grabbing. In this sense, we managed to interview a president of an anonymous housing cooperative about the spread of this urban movement in the city of Khenifra, and he answered accordingly:

... At a time when it is needed to keep its function as a collective social action, the creation of these housing cooperatives in Khenifra has become for some managers, a profitable investment without any capital of money. They agree as presidents of the housing cooperatives, to follow the procedure from the creation to the distribution of lots (ready housing lands for building), benefiting from a lot on the land for free if not a villa lot at the counterpart. They can also negotiate arrangements under the table, with the

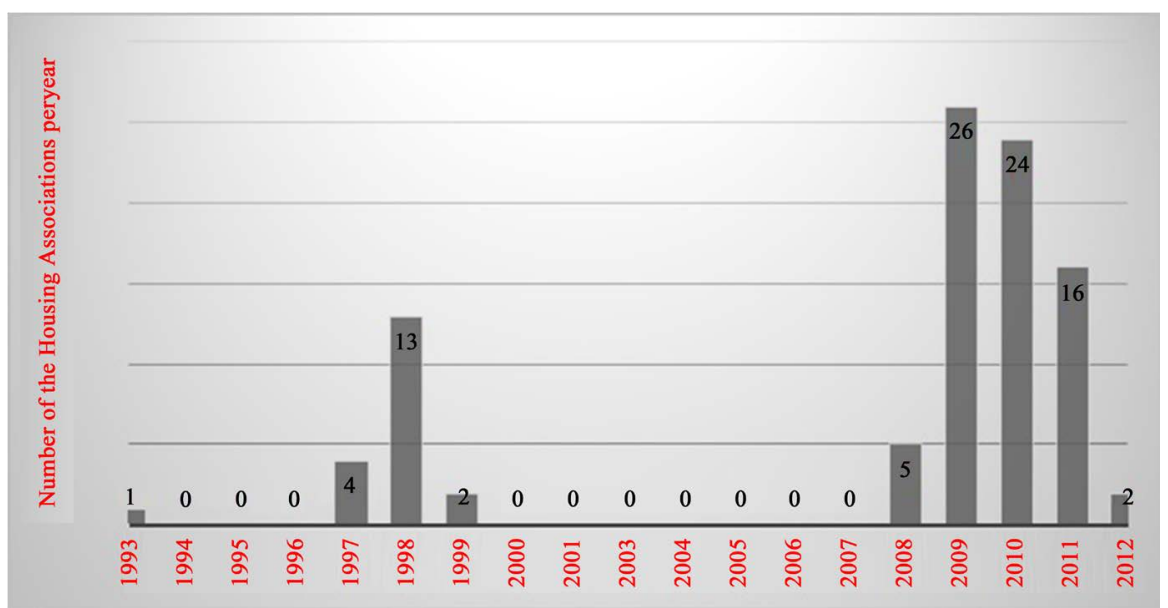

Source: The Urban Commune and the Pachalik of Khenifra in October 2014.

Figure 1. Evolution in the number of the housing cooperatives in the city of Khenifra between 1993 and 2012 . 
landowners and benefit from another profit. He continues, in my opinion, the laws governing these cooperatives must be reviewed, and above all the acceptance of the founding members of the association should condition their homelessness and landlessness.

\section{The Housing Cooperative and Urban Planning}

\subsection{A Downward Pressure for Management Plan Elaboration}

In the outlying areas of the city of Khenifra, the landowners exercise a downward pressure, on the occasion of each new delimitation of the development perimeter, so as to move their agricultural lands into the urban zoning (Abouhani, 1999). To provoke this pressure, they begin to sell these agricultural lands to groups of buyers organized in housing cooperatives, which by their number and their strong mobilization, can guide the provisions of Management Plan elaboration for their benefit, leaving empty spaces inside the city. Figure 2 shows how the Decommissioning Plan included the neighboring coastal farms of the city into a constructible zone ${ }^{9}$ between 1970 and 2014.

According to the information provided by the Land Registry Office in Khenifra, $87 \%$ of the surrounding land is owned by farmers, which makes the sprawl of the city over agriculture inevitable and inescapable, as it is indicated in Table 1.

Therefore, the chaotic urban sprawl over fertile farms must be tamed and reconsidered in an era where it becomes a public debate for sustainable urbanism and food crisis. Indeed, it is time for policy-makers and urban planners to reconsider their long-term strategies and assess the future of urban crawling and its grave consequences on agriculture, making informed and responsible decisions. In this way, leaving sustainable urbanism in the hands of other stakeholders can destroy the environment, food, land, water, and fertile farming. It is time to think about mountainous urbanization, where the rocky hillsides substitute the fertile lands for construction. When we say the hillsides, we mean the rocky side-hills surrounding the city and not the mountainous forests and natural parks. Indeed, side-hill badlands that can facilitate naturbanization of citizens and their easy access to the economic and social activities (Adjei Mensah, 2014; Huang, 2017), since many authors argued mountainous de-urbanization, instead, (Zhang, 2009; Barbero, Marques, \& Perez, 2013) for the protection of the natural parks and heritage (Marou et al., 2019). In this way, the rocky topography of the hillsides, surrounding the city of Khenifra would be convenient for urban expansion, as it is indicated in Figure 3.

\subsection{The Extension of the Management Perimeter on the Properties of Housing Cooperatives}

The city of Khenifra was in the urban area of $17,181,508 \mathrm{~m}^{2}$ in 2004 to expand

${ }^{9}$ Land in an area suitable for building. 


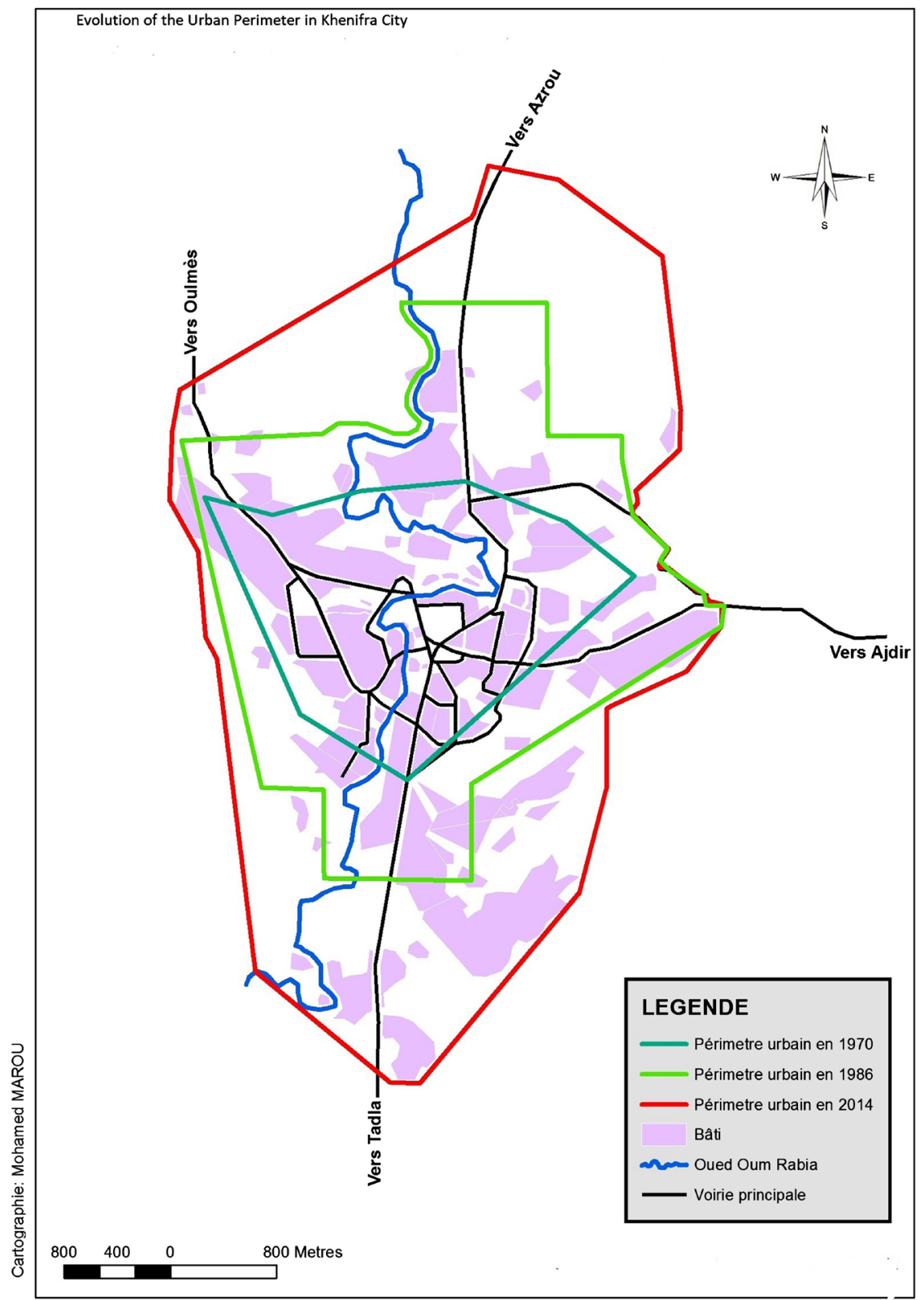

Source: Based on the Map drawn by H. Chabli in 1999 and the Development Plan of the city in 2014.

Figure 2. Evolution of the urban perimeter in Khenifra between 1970 and 2014.

Table 1. The status of urban land-ownership in Khenifra in 2014.

\begin{tabular}{ccc}
\hline Type of land ownership & Surface in $\mathbf{~ m}^{2}$ & $\%$ \\
\hline Habous-owned & 1673 & 0.01 \\
Military-owned & $1,410,000$ & 7.69 \\
Commune-owned & $651,957.2$ & 3.55 \\
State-owned & 272,700 & 1.48 \\
Private Farms & $16,005,109$ & 87 \\
Total & $18,331,439$ & 100 \\
\hline
\end{tabular}

Source: Land Registry in Khenifra. 


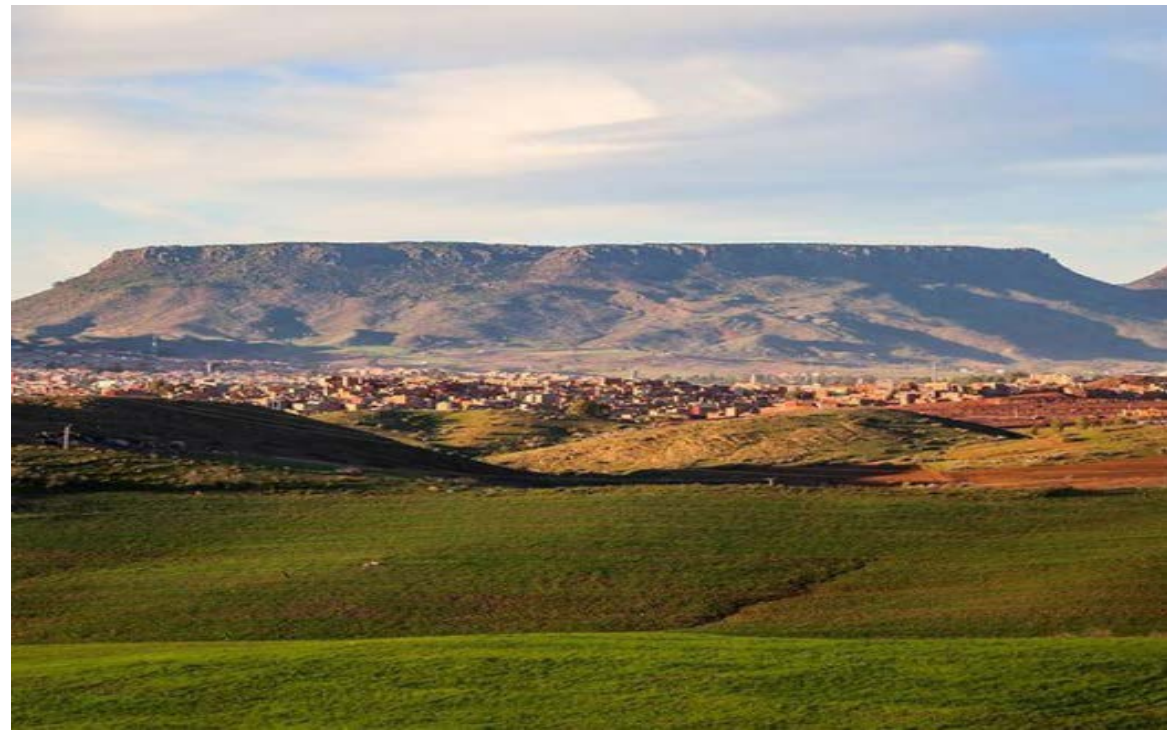

Source: https://www.pinterest.fr.

Figure 3. The rocky topography of the hillsides in Khenifra.

into 20,049,489 $\mathrm{m}^{2}$ in 2014 ( an extension in the order of 2,867,981 $\mathrm{m}^{2}$ ), among which $1,240,425 \mathrm{~m}^{2}$ of the urban land is occupied by the housing cooperatives created before the approval of the new Management Plan ${ }^{10}$, which means that $43.25 \%$ areas are open to urbanization. During the development of the city's Management Plan, all the housing cooperatives work hard to influence and modify the orientations of the urban plan for their benefit. Every association seeks to drag their pastoral or agricultural suburb lands in the building zoning of the city. In this way, implicit arrangements may be streamlined between the cooperative office and the design and technical offices for the development of the Management Plan, stepping over the logic of urban planning. Sometimes, the elected officials do explicitly, in a form of open criticism, express their demur and remonstrance against the draft plan, or implicitly during their public deliberations in their offices. The juxtaposition in opinions and interests seldom slows down or even blocks the development of the Management Plan, waiting for another decade to reopen deliberations anew. In this way, the city's urban space is doomed to a certain purposelessness and ergodicity in its governance and management, since the elected representatives always seek to please the interests of their inhabitants and landowners and not the inhabitedness of the convenient urban space.

\section{Housing Cooperatives: An Impediment for the Management Plan}

\subsection{The Problem of Collective Equipment Integration}

According to the rule of law 25 - 90 (Title 1, Article 1), any parcel of land, divided into two or more lots intended for the construction of buildings for resi${ }^{10}$ Changed every decade (10 years) in Morocco, It is the hot-key for the coming procedures and documentation for construction. 
dential, industrial, tourist, commercial or handicraft use, the allotment becomes the privileged framework for the programming and reservation of land intended to receive collective facilities and installations of general interest (DEP, 2005). Hence, when the parcel structure of the area allows it, the facilities will be an integral part of the allotments which will have to reserve the lands necessary for the needs of the populations. Otherwise, if the parcel structure does not allow it, or for any reason related to the nature or size of the facilities, the programming and reservation of the land will have to be done following the law $12-90$ related to urbanism. This new approach to programming, therefore, makes it imperative to use parcel plans when drawing up development plans, which is generally not the case and subsequently plunges urban planning into anarchy (Table 2).

According to the grid of urban standards, we perceive that 12 housing cooperatives do not meet the urban standards of community amenities and dwelling. This is currently a major problem for local planning managers in the city of Khenifra, which remains always an inquiry of the ongoing discussions. In other words, the Urban Agency proposes to involve the neighboring cooperatives to be able to reach areas that will allow them to insert the communal facilities of proximity, according to the normative grid, where other existing allotment authorization files are approved by the Provincial Commission of Big Projects.

\subsection{The Problem of Regulatory Compliance to the Management Plan}

The creative group of the housing cooperatives designs the zoning of its land, based on the following pre-calculations, beforehand:

- Subtracting $30 \%$ to $40 \%$ of the total land area as an area that will be reserved for equipment, roads and open spaces.

- The selection of $100 \mathrm{~m}^{2}$ as the minimum permitted area for construction.

- The number of members $=$ The remaining area divided over $100 \mathrm{~m}^{2}$.

Consequently, the members of the office begin to defend the zoning of their cooperative as a public inquiry during the first phase. Afterward, the members of the office begin to look for new adherents day in day out, in concordance with the Management Plan deliberations on the level of the Urban Agency ${ }^{11}$. Therefore and most of the time, when the latter is approved and the use of its land is different from its forecasts (for example: use by a structuring channel, use in villas areas, etc.), the cooperative office finds itself faced with a surplus of members which outnumbers the allotments number. In this case, the office in charge starts

Table 2. The Cadastral surface of the housing cooperatives in Khenifra city.

\begin{tabular}{cc}
\hline The Cadastral Surface & Number of Cooperatives \\
\hline Less than one hectare & 12 \\
From one to five hectares & 73 \\
\hline
\end{tabular}

Source: The Urban Commune of Khenifra city (November 2014).

${ }^{11} \mathrm{~A}$ public sector agency in charge of big and small construction projects validation. 
looking for a way out through the permission to parcel out after having missed this first opportunity. At this level, the office of the cooperative begins to renegotiate again the possibility to modify the widths of the road, as well as the minimum areas of the lots authorized to be built with the Local Committee of Urbanism. Then, operational planning is being phased out with the Management Plan regulation. For example, two applications (Taymate and El Borj Housing Cooperatives) for subdivision authorizations, of this kind, were examined out of twenty-eight files that have been submitted to the department of urban planning. Taymat housing cooperative is responsible for creating a $200 \mathrm{~m}^{2}$ villas area as a minimum for the building area. However, the examination of its technical file unveiled that the areas of its lots do not exceed $180 \mathrm{~m}^{2}$. Similarly, the second housing cooperative is allocated to the economic habitat zone of 110 $\mathrm{m}^{2}$ as the minimum area allowed to be built on the plan, where the areas of the lots are on the surface of $100 \mathrm{~m}^{2}$ and sometimes less. Hence, a large incongruity is created between the Committee of the City's Policy and Urbanism and the housing cooperatives.

\subsection{Offsite Equipment Problem}

As mentioned above, the housing cooperatives do shape the urban space in Khenifra. Most of them are concentrated in the northern part of the city, being the area most conducive to urbanization. Through the process of creation and integration, the cooperative dwellings initially created outside the development perimeter are integrated into it. Henceforward, they fell today in the problem of off-site equipment like sanitation, electricity, roads and other infrastructure services and works, delayed in the absence of a master plan which has not been developed so far. Finally, the city fell in a crisis of urban governance and planning, which blocks today the Management Plan implementation in the northern part of the city.

\section{Conclusion}

The city is not only a prominent site for agglomeration, it is a promotion of economic development and capital accumulation. Urbanization of society is part of its sustained development and the housing cooperatives still constitute a large harboring shelter for most of the citizen agglomerations in Morocco. The emergence of this associative movement and its remarkable development are real indicators of the State's inability to carry out a clear and relevant policy on the production of building ground and sustainable urbanism. Therefore, it is time for the planners and decision-makers to call upon the national engineering know-how in the field of sustainable urban planning and development in Morocco to respond to urban development with international standards. The kingdom's planners have to intervene to stop working with informality in the field of urbanism, curbing the randomized curse of urbanism sprawl at the expense of agriculture and green fields in the country on the expanse of informal and ar- 
cane real estate deals. Therefore, the purpose of this study is to determine how the housing cooperatives draw the urban map in Khenifra, where further investigation is encouraged in other Moroccan cities. Still, further solutions must be reproduced to cut the phenomenon.

\section{Conflicts of Interest}

The authors declare no conflicts of interest regarding the publication of this paper.

\section{References}

Abouhani, A. (1999). Pouvoirs, villes et notabilités locales: Quand les notables font les villes. Rabat: publié avec le concours de URBAMA. (OCLC: 493387190)

Adjei Mensah, C. (2014). Destruction of Urban Green Spaces: A Problem beyond Urbanization in Kumasi City (Ghana). American Journal of Environmental Protection, 3, 1-9. https://doi.org/10.11648/j.ajep.20140301.11

Barbero, C., Marques, M. J., \& Perez, M. (2013). The Case of Urban Sprawl in Spain as an Active and Irreversible Driving Force for Desertification. Journal of Arid Environments, 90, 95-102. https://doi.org/10.1016/j.jaridenv.2012.10.014

Carswell, A. T. (2012). The Encyclopedia of Housing (2nd ed.). London: SAGE. https://doi.org/10.4135/9781452218380

DEP (2005). Guide Des Cooperatives D’habitat. Ministère Délégué Chargé de l'Habitat et de l'Urbanisme.

El Malti, M. (2006). Le Foncier Urbain. http://elmalti.over-blog.com http://elmalti.over-blog.com/article-2134907.html

El Malti, M. (2013). L'urbanisme et la Question de la Ville. https://anthropohira.wordpress.com/2013/03/24/1956/ http://anthropohira.wordpress.com

Huang, G. (2017). Modeling Urban Spatial Growth in Mountainous Regions of Western China. Mountain Research and Development, 37, 367-376. https://doi.org/10.1659/MRD-JOURNAL-D-16-00078.1

Jari, D. (1999). Dynamique et Croissance Urbaine de la Ville De Khénifra. Poitiers, France: Université de Poitier. http://www.theses.fr http://www.theses.fr/1999POITA002

Lehzam, A. (1994). Le logement urbain au Maroc: Les ménages et l'Etat face à l'accès à la propriété et à la location. Rabat: CCMLA. (OCLC: 32878089)

Mandelker, D. R. (1981). Housing and Community Development: Cases and Materials. New York: Michie Company.

Marou, M. (2015). Les Mécanismes De La Fabrication d'une Ville Moyenne Au Maroc: Cas de La Ville de Khénifra. Unpublished Doctoral Dissertation, Rabat: INAU.

Marou, M., Azelmad, S., Hanzaz, M., \& Bouzidi, A. (2019). Heritage Governance between the Strategies of Actors and Territorial Development Opportunities: The Case of Khenifra in Morocco. Current Urban Studies, 7, 573-586.

https://doi.org/10.4236/cus.2019.74030

Perrin, R. (1989). Développement Local et Urbanisme. L'émergence de Nouvelles Compétences. Les Annales de la Recherche Urbaine, 44, 109-114.

https://www.persee.fr/doc/aru_0180-930x_1989_num_44_1_1486 
https://doi.org/10.3406/aru.1989.1486

Sazama, G. W. (2000). Lessons from the History of Affordable Housing Cooperatives in the United States: A Case Study in American Affordable Housing Policy. American Journal of Economics and Sociology, 59, 573-608.

https://onlinelibrary.wiley.com/doi/abs/10.1111/1536-7150.00045

https://doi.org/10.1111/1536-7150.00045

Zhang, B. P. (2009). Urbanization and De-Urbanization in Mountain Regions of China. Mountain Research and Development, 24, 206-209.

https://doi.org/10.1659/0276-4741(2004)024[0206:UADIMR]2.0.CO;2 